\title{
Mucosal bacteria in ulcerative colitis
}

\author{
S. Macfarlane ${ }^{1 *}$, E. Furrie ${ }^{1}$, A. Kennedy ${ }^{1}$, J. H. Cummings ${ }^{2}$ and G. T. Macfarlane ${ }^{1}$ \\ ${ }^{1}$ Microbiology and Gut Biology Group, University of Dundee, Dundee DD1 9SY, UK \\ ${ }^{2}$ Division of Pathology and Neuroscience, University of Dundee, Dundee DD1 9SY, UK
}

\begin{abstract}
Ulcerative colitis (UC) is an acute and chronic inflammatory bowel disease of unknown aetiology, although bacterial species belonging to the normal colonic microbiota are known to be involved in its initiation and maintenance. Several organisms have been linked to the disease; however, mucosa-associated bacteria are more likely to be involved than their luminal counterparts, due to their close proximity to the host epithelium. Comparative bacteriological analyses were done on rectal biopsies to investigate differences in mucosal bacteria in patients with UC and healthy controls. Complex bacterial communities were found in both groups, with significant reductions in bifidobacterial numbers in UC, which suggested that they might have a protective role in the disease. Accordingly, a therapy for treating UC was designed, with the aim of modifying the mucosal microbiota to increase bifidobacterial colonisation and reduce inflammation. Ranges of mucosal and faecal bifidobacteria were tested for their substrate preferences and their abilities to survive under a variety of environmental conditions. A synbiotic comprising a probiotic (Bifidobacterium longum) isolated from healthy rectal mucosa combined with a prebiotic (oligofructose-enriched inulin - Synergy $1^{\mathrm{TM}}$ ) was developed. The treatment was used in a randomised controlled trial involving eighteen patients with active UC, for a period of 1 month. Rectal biopsies were collected at the beginning and end of the study. Bacteriological analysis and transcription levels of epithelium-related immune markers were assessed. Results demonstrated that short-term synbiotic treatment resulted in increased bifidobacterial colonisation of the rectal mucosa and induced significant reductions in the expression of molecules that control inflammation in active UC.
\end{abstract}

Probiotics: Prebiotics: Synbiotics: Ulcerative colitis: Mucosal bacteria

Ulcerative colitis (UC) and Crohn's disease are the two major forms of idiopathic inflammatory bowel disease (IBD). The inflammatory response in UC is primarily located in the colonic mucosa and submucosa, and the distal colon is always affected. The disease may progress towards the proximal bowel, with severe tissue damage, resulting in ulceration and haemorrhage.

Evidence from animal models suggests that healthy individuals have a tolerance to their own bacteria which is broken down in IBD, and that an altered immune response towards the commensal gut microbiota plays a key role in the development and maintenance of this condition (Butcher, 1991; Duchman et al. 1995; Macdonald et al. 2000; Campieri \& Gionchetti, 2001). UC patients have been shown to have increased antibody production against strictly anaerobic species (Monteiro et al. 1971; Tvede et al. 1983; Bamba et al. 1995; Furrie et al. 2004) and increased levels of mucosal $\mathrm{IgG}$ against the normal colonic microflora (Macpherson et al. 1996).

Early work implicated bacterial involvement in both the initiation and maintenance of the inflammatory processes of UC (Hill, 1986; Cummings et al. 2003). Animal studies demonstrated that antimicrobial agents specifically active against obligate anaerobes prevented ulceration in guinea pigs (Onderdonk \& Bartlett, 1979), and that germ-free animals only develop colitis when repopulated with bacteria (Sadlack et al. 1993; Taurog et al. 1994).

A variety of species including fusobacteria, shigella (Onderdonk, 1983) and, more recently, salmonella and yersinia have been linked to UC (Sartor et al. 1996). In some studies, higher numbers of facultative anaerobes have been reported in faeces from IBD patients (Onderdonk, 1983; Seksik et al. 2003). Escherichia coli was one of the first bacteria to be implicated in UC (Monteiro et al. 1971; van der Waaij et al. 1974) and subsequent studies suggested that isolates from UC patients were more adherent than those from healthy people or patients with infectious diarrhoea (Burke \& Axon, 1988; Chadwick, 1991). Later work suggested that E. coli occurred in low numbers in UC tissue (Walmsey et al. 1998) and that there was no increased adherence in the disease (Hartley et al. 1993; Schultsz et al. 1997). However, to date, there is no evidence for a specific transmissible agent in UC.

Conventional treatment for UC usually involves suppression or modulation of the host inflammatory response using corticosteroids, aminosalicylates or immunomodulatory agents, depending on the severity and localisation of the disease. However, some individuals cannot tolerate these treatments, and they can have various debilitating side-effects (Navarro \& Hanauer, 2003). The few studies using antibiotics to treat UC in man have suggested that they are of limited use. However, animal studies indicate that antibiotics can be beneficial if given before the onset of colitis (Cummings et al. 2003). Antibiotic resistance can also develop, and unless specifically targeted, antibiotics can cause severe disturbances in the microbiota. Moreover, bacteria involved in inflammatory processes in UC probably grow in biofilms on the mucosa, which have been shown to be resistant to antibiotics (Anwar et al. 1990). 
Therefore, the use of other therapeutic methods to manipulate the composition and activities of mucosal bacterial communities may provide a useful alternative in the treatment of UC.

\section{Probiotics, prebiotics and synbiotics}

Probiotics, prebiotics and synbiotics are food ingredients that confer a beneficial effect beyond that of their nutritional content alone (Shanahan \& McCarthy, 2000). Probiotics are live microbial feed supplements that change either the composition and/or metabolic activities of the microbiota, or modulate host immune system reactivity in such a way that benefits health (Macfarlane \& Cummings, 2002). Prebiotics have been defined as non-digestible oligosaccharides that selectively stimulate one or a limited number of bacterial species in the colon in a way that benefits health (Gibson \& Roberfroid, 1995). Prebiotics can act as substrates for the growth of beneficial bacteria, such as bifidobacteria and lactobacilli, which are already present in the colon, to maintain a health-promoting microbiota and enhance colonisation resistance. The most common prebiotics are inulin-type fructans that occur naturally in plants such as artichoke, onion, banana and chicory root. Longer chain lengths are termed inulin and shorter molecules oligofructose. Commercial forms are mainly created by extraction from chicory roots or by synthesis from sucrose (Niness, 1999). The combination of a probiotic and prebiotic is termed a synbiotic. The rationale behind this concept is that the prebiotic preferentially stimulates growth of the probiotic, although it will also affect other bacteria in the gut.

There is increasing evidence that the use of functional foods such as probiotics can reduce the severity of IBD, and that they may be beneficial as maintenance therapy (Gionchetti et al. 2000). However, their effects on the commensal microbiota and the host immune system need to be determined, since the immunomodulatory properties of probiotic bacteria vary widely (He et al. 2000; Maassen et al. 2000; Ibnou-Zekri et al. 2003). The most widely used probiotics in man are bifidobacteria and lactobacilli, but other organisms such as E. coli and the yeast Saccharomyces boulardii have been reported to have some beneficial effects in maintaining remission in IBD (Kruis et al. 1997; Rembacken et al. 1999; Guslandi et al. 2000). Other evidence linking the use of probiotics with health benefits in UC have come from animal studies. Lactobacillus reuterii has been shown to reduce the effects of colitis induced by acetic acid (Fabia et al. 1993a) and methotrexate (Mao et al. 1996) and to prevent spontaneous colitis developing in IL-10-deficient mice (Madsen et al. 1999). In another study, Lactobacillus plantarum $299 \mathrm{~V}$ reduced mucosal IgG, interferon- $\gamma$ and IL-12, and attenuated inflammatory responses in the IL-10, mouse model of colitis (Schultz et al. 2002). A genetically engineered Lactococcus lactis, which secretes IL-10, was able to reduce colitis by $50 \%$ in two mouse models (Steidler et al. 2000).

Pouchitis is a frequent and chronic complication that occurs after pouch surgery for UC. Reduced numbers of lactobacilli have been found in colonic biopsies from pouchitis patients (Fabia et al. 1993b), as well as lower numbers of lactobacilli and bifidobacteria in gut contents (Ruseler van Embden et al. 1994). A probiotic mixture VSL3 containing eight different organisms has been reported to be effective in maintaining remission in chronic pouchitis (Gionchetti et al. 2000), and was believed to be effective in treating UC patients (Venturi et al. 1999) allergic to compounds based on 5-aminosalicylic acid.
However, it is unclear how the bacteria in this mixture interact with each other and the host in vivo, and there are potential safety issues with the use of probiotics as a therapy for UC. For example, Lactobacillus rhamnosus was found to cause sepsis in a UC patient (Farina et al. 2001), while Enterococcus faecalis induces IBD in mice (Balish \& Warner, 2002).

\section{Mucosal bacteria in ulcerative colitis}

The luminal microflora of UC patients has been examined in many studies (van der Wiel-Korstanje \& Winkler, 1975; von Wulffen et al. 1989), but little work has been done on mucosal bacterial communities in UC. However, since the mucosa is the principal site of inflammation in UC, it is likely that mucosal bacteria, due to their closer proximity to host tissues, are able to interact directly with the host immune system and initiate the inflammatory response. Bacterial populations colonising the large intestinal epithelium are known to be different in composition to those that occur in the gut lumen (Macfarlane et al. 1999, 2000). Recently, using molecular techniques, significant differences were observed in mucosal and faecal microflora (Zoetendal et al. 2002). Studies on colonic biopsies from the healthy gut have shown that although mucosal bacteria are able to adhere directly to the bowel wall, the organisms are present in higher numbers in the mucus layer (Hartley et al. 1993).

Using culturing methods, Poxton et al. (1997) found no significant differences in bacteria growing on mucosal surfaces in UC patients and controls with non-inflammatory bowel conditions. Bacteroides predominated in both groups, with Bacteriodes thetaiotaomicron being more prevalent in UC. Other studies have found high numbers of bacteria on UC mucosa compared to controls (Schultsz et al. 1999; Swidsinski et al. 2002). A recent investigation on mucosal biopsies from active UC and Crohn's patients, using a combination of cloning, single-strand conformational polymorphism fingerprinting and real-time PCR, reported a reduction in bacterial diversity occurred in IBD patients, with reduced numbers of bacteroides and enterobacteria (Ott et al. 2004). A number of investigations have used molecular techniques such as fluorescence in situ hybridisation (FISH) and real-time PCR, which do not require bacteria to be cultured. However, although they can compare differences in the genetic composition of mucosal microbiota, they provide no information on the viability of the bacteria, their effects on the immune system or other characteristics that determine their role in UC or suitability for probiotic use in UC therapy.

\section{Characterisation of the mucosal flora}

Because of the putative role of mucosal biofilms in UC aetiology, we compared mucosal bacterial communities colonising the rectal epithelium in nineteen individuals (nine UC, ten normal). All biopsies taken during endoscopy were of inflamed tissue from patients that had mild or moderately severe UC. Rectal biopsies were used in these studies because UC always starts in this region of the large bowel, and the gut did not need to be cleansed, with the attendant risk of disturbing the microbiota. Tissue samples were immediately transported to the laboratory and plated onto a range of selective and non-selective agars. The bacteria were then characterised on the basis of their Gram staining characteristics, cellular morphology and cellular fatty acid methyl ester profiles using the MIDI system. FISH analysis 
with a variety of $16 \mathrm{~S}$ rRNA probes was also used to visualise bacterial colonisation of the mucosa.

Complex bacterial communities were found in both healthy people and UC patients (Macfarlane et al. 2004). Total bacterial counts ranged from $10^{4}$ to $10^{6} \mathrm{~cm}^{2}$ in both groups. In total, seventy-two bacterial taxa belonging to eighteen genera were found and anaerobic bacteria outnumbered facultative anaerobes in both UC and healthy subjects. In both groups, bacteroides-occurred in the highest numbers, although facultative anaerobes were found in proportionately much higher numbers than in faecal material. The predominant facultative species was E. coli. Unlike the other major groups of bacteria colonising the rectal epithelium, bifidobacterial populations were significantly different in UC with mean counts being 30 -fold higher in non-UC. Bifidobacterium adolescentis was the most prevalent in non-UC, whereas Bifidobacterium angulatum predominated in UC patients. B. angulatum and $B$. bifidum were found in both UC and healthy subject groups. Low numbers of bifidobacteria or the absence of particular bifidobacterial taxa on the mucosa may be of significance in UC because some species exhibit strong immunomodulatory properties (Ruseler van Embden et al. 1994). Other investigators have also reported major reductions in bifidobacteria on the gut mucosa in IBD patients, together with increased bacteroides (Pathmakanthan et al. 1999). Bifidobacteria and peptostreptococci are highly immunogenic in UC patients (Furrie et al. 2004), suggesting that the presence or absence of these organisms may be linked to the disease process. Peptostreptococci and E. faecalis were not found on the rectal mucosa in healthy people, but did occur in UC patients. Matsuda et al. (2000) also found that peptostreptococci only occurred on mucosal surfaces in UC.

Microscopic analysis using a live/dead stain and 16S rRNA probes applied directly onto the rectal epithelium showed that the majority of the bacteria were living, suggesting that they were actively growing on the gut surface. Many of the organisms such as bacteroides, bifidobacteria and enterococci in UC patients were seen growing in microcolonies, which may have implications for UC, since this form of colonisation would result in higher localised concentrations of bacterial antigens, or toxins, than would be the case if the organisms were diffusely spread across the mucosa.

\section{Probiotic development and production}

Ten bifidobacterial isolates from healthy colonic mucosa were assessed for their suitability as probiotics, and were compared to five isolates from faeces provided by healthy donors and four culture collection strains. In all six strains of $B$. adolescentis, two Bifidobacterium bifidum, two Bifidobacterium infantis (DSM 86184, ATCC 15617) two Bifidobacterium longum, and one each of B. angulatum, Bifidobacterium breve, Bifidobacterium catenulatum, Bifidobacterium dentium, Bifidobacterium lactis (DSM 10140), Bifidobacterium pseudocatenulatum and Bifidobacterium suis (ATCC 17533), were tested. To determine the suitability of the isolates as potential probiotics, the organisms were assessed for aero tolerance, acid tolerance, bile salt resistance, adhesion to epithelial cells, and their abilities to utilise various prebiotic substrates. Their abilities to survive freeze drying and long-term storage were also determined.

A B. longum strain isolated from healthy rectal mucosa was selected as the most suitable candidate to use in a feeding trial. Its identity was confirmed by partial sequencing (500 of
$1500 \mathrm{bp}$ ) of the variable region of the $16 \mathrm{~S}$ rRNA gene. The ability of this isolate to effect expression of the pro-inflammatory cytokines IL- $1 \alpha$, TNF $\alpha$ and IL- 8 in a HT29 epithelial cell line was also determined by real-time PCR, by measuring mRNA levels and cytokine ELISA for secreted proteins. The bacterium significantly reduced mRNA synthesis and protein levels of IL- $1 \alpha$ produced by HT29, and did not stimulate TNF $\alpha$ and IL- 8 . The organism was then grown overnight under anaerobic conditions at $37^{\circ} \mathrm{C}$ in Wilkins-Chalgren broth, centrifuged at $14000 \mathrm{~g}$ for $30 \mathrm{~min}$ and washed twice in anaerobic PBS. The pellet was frozen overnight at $-80^{\circ} \mathrm{C}$, lyophilised and stored at $4^{\circ} \mathrm{C}$. Cell viability and purity were checked during the production and packaging of the probiotic and throughout the study.

\section{Synbiotic feeding study}

A synbiotic combining the probiotic B. longum isolate and the prebiotic oligofructose-enriched inulin (Synergy $1^{\mathrm{TM}}$; Orafti, Tienen, Belgium) was then used in a double-blinded randomised controlled trial lasting 1 month (Furrie et al. 2005). Oligofructoseenriched inulin was chosen as it was found to be the preferential prebiotic growth substrate for B. longum.

Eighteen patients with active UC (age 24-67 years) were selected from a gastroenterology outpatient clinic for the study. Patients receiving the synbiotic were given $2 \times 10^{11}$ freeze-dried viable $B$. longum in a gelatin capsule, and a sachet containing $6 \mathrm{~g}$ of the prebiotic twice daily for 4 weeks. Placebos were given an identical capsule containing potato starch and sachets containing $6 \mathrm{~g}$ of powdered maltodextrin to simulate the prebiotic. To minimise the inhibitory effects of gastric acid on the bifidobacterium, the capsules were taken after breakfast and after the evening meal. At each visit, at the start and end of the study period, clinical status was scored, rectal biopsies were collected and transcription levels of epithelium-related immune markers measured. Mucosal bifidobacterial populations were compared using quantitative real-time PCR.

Currently, the main way of measuring the inflammatory status of an individual with IBD is by sigmoidoscopy and histology. However, with the advent of new more sensitive molecular methods, such as real-time PCR, changes in the levels of gene expression of inflammatory markers can now be quantified (Furrie et al. 2005). Pro-inflammatory cytokines such as TNF $\alpha$, IL-8, IL- $1 \alpha$ and IL-1 $\beta$ are up-regulated in active UC, and levels of $\mathrm{TNF} \alpha$ have been shown to be significantly reduced after administration of probiotics ex vivo to colonic biopsies from Crohn's patients (Borruel et al. 2002). However, these cytokines can be expressed by other infiltrating cells in the mucosa (Woywodt et al. 1999; Daig et al. 2000; Borruel et al. 2002), and do not therefore provide a clear picture of what is happening in the epithelial cells.

To circumvent this, levels of human $\beta$-defensins (hBD), which are antimicrobial peptides expressed uniquely by epithelial cells in the intestine (Zhao et al. 1996; Yamaguchi et al. 2002), were quantified by real-time PCR. There are currently six hBD (hBD1-6) recognised, and hBD2-3 are known to be up-regulated, by bacterial challenge and the formation of pro-inflammatory cytokines (O'Neil et al. 1999, 2003). In Crohn's disease, the $\mathrm{hBD} 2$ and 3 responses are reduced, whereas in UC, hBD2 and 3 have been shown to be significantly up-regulated (O'Neil et al. 1999; Fellerman et al. 2003; Wehkamp et al. 2003).

mRNA for hBD2 was significantly reduced in the test group after 4 weeks of synbiotic consumption (Fig. 1). Marked 


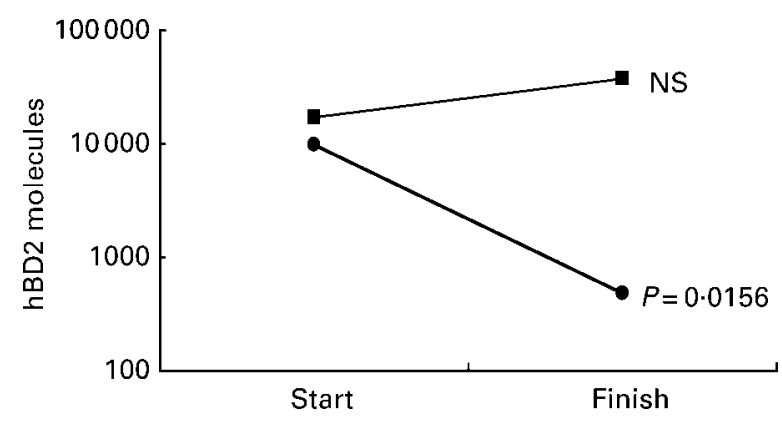

Fig. 1. Levels of inducible human $\beta$-defensin 2 (hBD2) mRNA in mucosal tissue before and after 4 weeks' consumption of synbiotic or placebo. The difference between pre- and post-feeding in the synbiotic group was significant $(P=0.016)$. Results are normalised for epithelial cell numbers by determining levels of hBD1, the constitutive epithelial cell house-keeping gene.

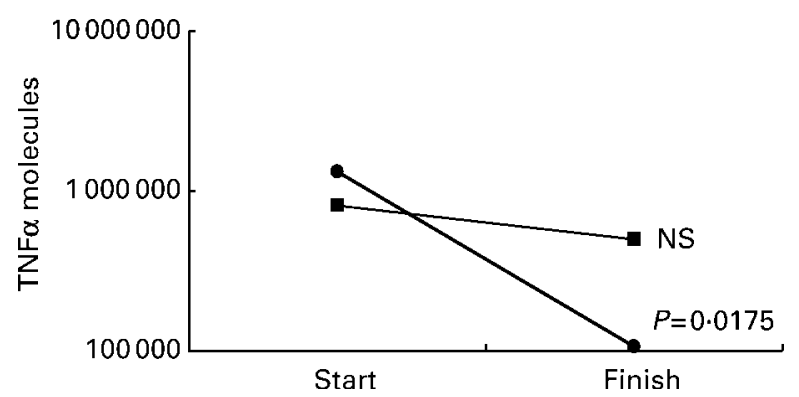

Fig. 2. Cytokine TNF $\alpha$ mRNA concentrations in mucosal tissue before and after 4 weeks' consumption of synbiotic or placebo. The difference in the synbiotic group between pre- and post-feeding was significant $(P=0.017)$. Levels are normalised for total cells per biopsy using glyceraldehyde 3-phosphate dehydrogenase.

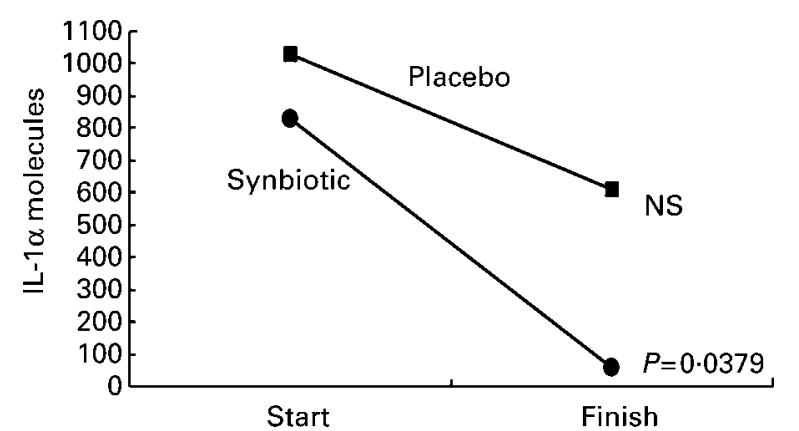

Fig. 3. Cytokine IL-1 $\alpha$ mRNA concentrations in mucosal tissue before and after 4 weeks' consumption of synbiotic or placebo. The difference in the synbiotic group between pre- and post-feeding was significant $(P=0.038)$. Levels are normalised for total cells per biopsy using glyceraldehyde 3-phosphate dehydrogenase.

reductions were also seen in the levels of the pro-inflammatory cytokines, TNF $\alpha$ and IL- $1 \alpha$, that induce defensin expression (Figs 2 and 3). In the most severely ill patients, C-reactive protein fell to normal levels. Regeneration of the epithelium and a decrease in inflammation occurred in the synbiotic patients at the end of the trial, with reductions in both histology and sigmoidoscopy (Fig. 4) scores. However, they did not reach statistical significance, which may have been due to the short duration of the trial. A 42-fold increase in bifidobacterial colonisation was seen in mucosal biopsies in the synbiotic group, compared to a 4.6-fold increase in the placebo group (Fig. 5).

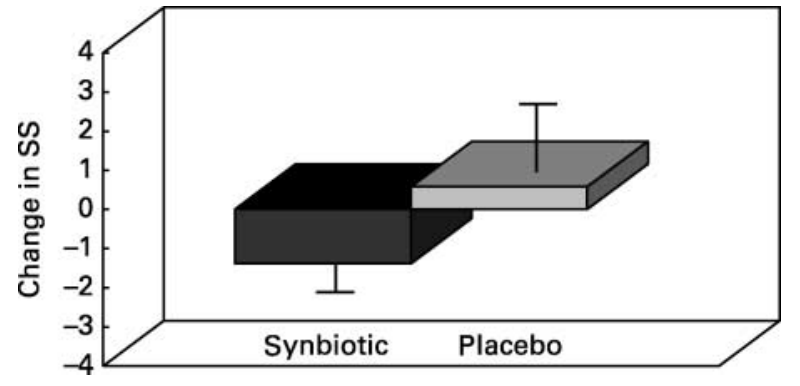

Fig. 4. Clinical outcome for patients assessed by sigmoidoscopy score (SS). Results are expressed as the difference in values recorded at day 1 and day 28 of the trial. The difference in pre- and post-feeding between the synbiotic and placebo groups was approaching significance $(P=0.06)$.

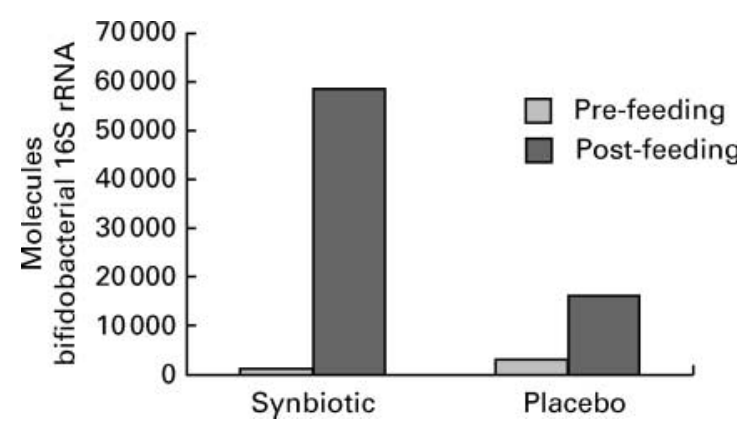

Fig. 5. Levels of bifidobacteria-specific total 16S rRNA in mucosal biopsies pre- and post-feeding determined using real-time PCR. The synbiotic group demonstrated a 42 -fold increase and the placebo group a 4.6-fold increase over the 4 weeks of the study. The samples were normalised for numbers of epithelial cells by human $\beta$-defensin 1 levels.

\section{Summary}

Highly complex microbial communities colonise the human gut mucosa in health and disease. Circumstantial evidence suggests that these mucosal biofilms may be involved in the aetiology of colitis. The development of a synbiotic therapy for UC, comprising a probiotic $B$. longum isolated from the rectal mucosa of a healthy individual, in combination with a prebiotic growth substrate, was shown to reduce significantly the levels of inflammatory markers in active UC during a 1-month feeding trial. A reduction in inflammation was also seen at the clinical level, in histology and sigmoidoscopy scores. A large-scale clinical trial is now needed to investigate the long-term effects of synbiotic use in inducing and maintaining remission in patients with active disease.

\section{References}

Anwar H, Dasgupta MK \& Costerton JW (1990) Testing the susceptibility of bacteria in biofilms to antibacterial agents. Antimicrob Agents Chemother 34, 2043-2046.

Balish E \& Warner T (2002) Enterococcus faecalis induces inflammatory bowel disease in interleukin-10 knockout mice. Am J Pathol 160, 2253-2257.

Bamba T, Matsuda H, Endo M \& Fujiyama Y (1995) The pathogenic role of Bacteroides vulgatus in patients with ulcerative colitis. J Gastroenterol 30, Suppl. 8, 45-47.

Borruel N, Carol M, Casallas F, Antolin M, de Lara F, Espin E, Naval J, Guarner F \& Malagelada JR (2002) Increased mucosal tumour necrosis 
factor $\alpha$ production in Crohn's disease can be down regulated ex vivo by probiotic bacteria. Gut 51, 659-664.

Burke D \& Axon A (1988) Adhesive E. coli in inflammatory bowel disease and infective diarrhoea. $\mathrm{Br}$ Med $J$ 297, 102-104.

Butcher EC (1991) Leukocyte-endothelial cell recognition: three (or more) steps to specificity and diversity. Cell 67, 1033-1036.

Campieri M \& Gionchetti P (2001) Bacteria as the cause of ulcerative colitis. Gut 48, 132-135.

Chadwick VS (1991) Etiology of chronic ulcerative colitis and Crohn's disease. In The Large Intestine: Physiology, Pathophysiology and Disease, pp. 445-463 [SF Phillips, JH Pemberton and RG Shorter, editors]. New York: Raven Press.

Cummings JH, Macfarlane GT \& Macfarlane S (2003) Intestinal bacteria and ulcerative colitis. Curr Issues Intest Microbiol 4, 9-20.

Daig R, Rogler G, Aschenbrenner E, Vogl D, Falk W, Gross V, Scholmerich J \& Andus T (2000) Human intestinal epithelial cells secrete interleukin-1 receptor antagonist and interleukin- 8 but not interleukin- 1 or interleukin-6. Gut 46, 350-358.

Duchman R, Kaiser I, Hermann E, Mayet W, Ewe K \& Meyer Zum KH (1995) Tolerance exists towards resident intestinal flora but is broken down in active inflammatory bowel disease (IBD). Clin Exp Immunol 102, 448-455.

Fabia R, Ar'Rajab A, Johansson ML, Willen R, Molin G \& Bengmark S (1993a) The effect of exogenous administration of Lactobacillus reuteri R2LC and oat fiber on acetic acid-induced colitis in the rat. Scand J Gastroenterol 28, 155-162.

Fabia R, Ar'Rajab A, Johansson ML, Andersson R, Willen R, Jeppsson B, Molin G \& Bengmark S (1993b) Impairment of bacterial flora in human ulcerative colitis and experimental colitis in the rat. Digestion 54, 248-255.

Farina C, Arosio M, Mangia M \& Moioli F (2001) Lactobacillus casei subsp. rhamnosus sepsis in a patient with ulcerative colitis. J Clin Gastroenterol 33, 251-252.

Fellerman K, Wehkamp J, Herrlinger KR \& Stange EF (2003) Crohn's disease: a defensin deficiency syndrome? Eur J Gastroenterol Hepatol 15, 627-634

Furrie E, Macfarlane S, Cummings JH \& Macfarlane GT (2004) Systemic antibodies towards mucosal bacteria in ulcerative colitis and Crohn's disease differentially activate the innate immune response. Gut 53, 92-99.

Furrie E, Macfarlane S, Kennedy A, Cummings JH, Walsh SV, O’Neil DA \& Macfarlane GT (2005) Synbiotic therapy (Bifidobacterium longum/ Synergy $1^{\mathrm{TM}}$ ) initiates resolution of inflammation in patients with active ulcerative colitis: a randomised controlled pilot trial. Gut 54, $242-249$.

Gibson GR \& Roberfroid MB (1995) Dietary modulation of the human colonic microbiota introducing the concept of prebiotics. J Nutr $\mathbf{1 2 5}$, $1401-1412$

Gionchetti P, Rizzello F, Venturi A, Brigidi P, Matteuzzi D, Bazzocchi G, Poggioli G, Miglioli M \& Campieri M (2000) Oral bacteriotherapy as maintenance treatment in patients with chronic pouchitis: a doubleblind, placebo-controlled trial. Gastroenterology 119, 305-309.

Guslandi M, Mezzi G, Sorghi M \& Testoni PA (2000) Saccharomyces boulardii in maintenance treatment of Crohn's disease. Dig Dis Sci 45, 1462-1464.

Hartley MG, Hudson MJ, Swarbrick ET, Gent AE, Hellier MD \& Grace RH (1993) Adhesive and hydrophobic properties of Escherichia coli from the rectal mucosa of patients with ulcerative colitis. Gut 34, 63-67.

He F, Tuomola E, Arvilommi H \& Seppo S (2000) Modulation of humoral immune response through probiotic intake. FEMS Immunol Med Microbiol 29, 47-52.

Hill MJ (1986) The possible role of bacteria in inflammatory bowel disease. Curr Concepts Gastroenterol 3,10-14.

Ibnou-Zekri N, Blum S, Schiffrin EJ \& von der Weid T (2003) Divergent patterns of colonization and immune response elicited from two intestinal Lactobacillus strains that display similar properties in vitro. Infect Immun 71, 428-436.
Kruis W, Schutz Fric P, Fixa B, Judmaier G \& Stolte M (1997) Doubleblind comparison of an oral Escherichia coli preparation and mesalazine in maintaining remission in ulcerative colitis. Aliment Pharmacol Ther 11, 853-858.

Maassen CB, van Holten-Neelen C, Balk F, den Bak-Glashouwer MJ, Leer RJ, Lamen JD, Boersma WJ \& Claassen E (2000) Strain-dependent induction of cytokine profiles in the gut by orally administered Lactobacillus strains. Vaccine 18, 2613-2623.

Macdonald TT, Monteleone G \& Pender SLF (2000) Recent developments in the immunology of inflammatory bowel disease. Scand J Immunol 51, 2-9.

Macfarlane GT \& Cummings JH (2002) Probiotics, infection and immunity. Curr Opin Infect Dis 15, 501-506.

Macfarlane S, Cummings JH \& Macfarlane GT (1999) Bacterial colonisation of surfaces in the large intestine. In Colonic Microflora, Nutrition and Health, pp. 71-87 [GR Gibson and M Roberfroid, editors]. London: Chapman \& Hall.

Macfarlane S, Hopkins MJ \& Macfarlane GT (2000) Bacterial growth and metabolism on surfaces in the large intestine. Microb Ecol Health Dis 2, 64-72.

Macfarlane S, Furrie E, Cummings JH \& Macfarlane GT (2004) Chemotaxonomic analysis of bacterial populations colonizing the rectal mucosa in patients with ulcerative colitis. Clin Infect Dis $\mathbf{3 8}$ 1690-1699.

Macpherson A, Khoo UY, Forgacs I, Philpott-Howard J \& Bjarnason I (1996) Mucosal antibodies in inflammatory bowel disease are directed against intestinal bacteria. Gut 38, 365-375.

Madsen KL, Doyle JS, Jewell LD, Tavernini MM \& Fedorak RN (1999) Lactobacillus species prevent colitis in interleukin 10 gene-deficient mice. Gastroenterology 116, 1107-1114.

Mao Y, Nobaek S, Kasravi B, Adawi D, Stenram U, Molin G \& Jeppsson B (1996) The effects of Lactobacillus strains and oat fiber on methotrexate-induced enterocolitis in rats. Gastroenterology 111, 334-344.

Matsuda H, Fujiyama Y, Andoh A, Ushijima T, Kajinami T \& Bamba T (2000) Characterization of antibody responses against rectal mucosaassociated bacterial flora in patients with ulcerative colitis. J Gastroenterol Hepatol 15, 61-68.

Monteiro E, Fossey J, Shiner M, Draser BS \& Allison AC (1971) Antibacterial antibodies in rectal and colonic mucosa in ulcerative colitis Lancet 1, 249-251.

Navarro F \& Hanauer SB (2003) Treatment of inflammatory bowel disease: safety and tolerability issues. Am J Gastroenterol 98, S18-S23.

Niness KR (1999) Inulin and oligofructose: what are they? British J Nutr 129, Suppl. 7, 1402S-1406S.

Onderdonk AB (1983) Role of the intestinal microflora in ulcerative colitis. In Human Intestinal Microflora in Health and Disease, pp. 481-493 [DJ Hentges, editor]. New York: Academic Press.

Onderdonk AB \& Bartlett MD (1979) Bacteriological studies of experimental ulcerative colitis. Am J Clin Nutr 32, 258-265.

O'Neil DA (2003) Regulation of expression of beta-defensins: endogenous enteric peptide antibiotics. Mol Immunol 40, 445-450.

O'Neil DA, Porter EM, Elewaut D, Anderson GM, Eckmann L, Ganz T \& Kagnoff MF (1999) Expression and regulation of the human betadefensins hBD-1 and hBD-2 in intestinal epithelium. $J$ Immunol 163, 6718-6724.

Ott SJ, Musfeldt M, Wendererorh DF, Hampe J, Brant O, Folsch UR, Timmis KN \& Schrieiber S (2004) Reduction in diversity of the colonic mucosa associated microflora in patients with active inflammatory bowel disease. Gut 53, 685-693.

Pathmakanthan S, Thornley JP \& Hawkey CJ (1999) Mucosally associated bacterial flora of the human colon: quantitative and species specific differences between normal and inflammed colonic biopsies. Microb Ecol Health Dis 11, 169-174.

Poxton IR, Brown R, Sawyerr A \& Ferguson A (1997) Mucosa-associated bacterial flora of the human colon. J Med Microbiol 46, 85-91.

Rembacken BJ, Snelling AM, Hawkey PM, Chalmers DM \& Axon ATR (1999) Non-pathogenic Escherichia coli versus mesalazine for the 
treatment of ulcerative colitis: a randomised trial. Lancet 354, 636-639.

Ruseler van Embden JGH, Schouten WR \& Van Lieshout LMC (1994) Pouchitis: result of microbial imbalance? Gut 35, 658-664.

Sadlack B, Merz H \& Schorle H (1993) Ulcerative colitis-like disease in mice with a disrupted interleukin-2 gene. Cell 175, 253-261.

Sartor RB, Rath HC \& Sellon HK (1996) Microbial factors in chronic intestinal inflammation. Curr Opin Gastroenterol 12, 327-333.

Schultsz C, Moussa M, van Ketel R, Tytgat GN \& Dankert J (1997) Frequency of pathogenic and enteroadherent Escherichia coli in patients with inflammatory bowel disease and controls. J Clin Pathol 50, $573-579$

Schultsz C, Van der Berg FM, ten Kate FW, Tytgat GN \& Dankert J (1999) The intestinal mucous layer from patients with inflammatory bowel disease harbors high numbers of bacteria compared with controls. Gastroenterology 117, 1089-1097.

Schultz M, Veltkamp C \& Dieleman LA (2002) Lactobacillus plantarum $299 \mathrm{~V}$ in the treatment and prevention of spontaneous colitis in interleukin-10-deficient mice. Inflamm Bowel Dis 8, 71-80.

Seksik P, Rigottier-Gois L, Gramet G, Sutren M, Pochart P, Marteau P, Jian R \& Dore J (2003) Alterations of the dominant faecal bacterial groups in patients with Crohn's disease of the colon. Gut 52, $237-242$.

Shanahan F \& McCarthy J (2000) Functional foods and prebiotics - time for gastroenterologists to embrace the concepts. Curr Gastroenterol Rep 2, 345-346.

Steidler L, Hans W, Schotte L, Neirynck S, Obermeier F, Falk W, Fiers W \& Remaut E (2000) Treatment of murine colitis by Lactococcus lactis secreting interleukin-10. Science 289, 1352-1355.

Swidsinski A, Ladhoff A, Pernthaler A, et al. (2002) Mucosal flora in inflammatory bowel disease. Gastroenterology 122, 44-54.

Taurog JD, Richardson JA, Croft JT, Simmons WA, Zhou M, FernandezSueiro JL, Balish E \& Hammer RE (1994) The germ free state prevents development of gut and joint inflammatory disease in HLA-B27 transgenic rats. $J$ Exp Med 180, 2359-2364.

Tvede M, Bondesen S, Nielsen OH \& Rasmussen SN (1983) Serum antibodies to Bacteroides species in chronic inflammatory bowel disease. Scand J Gastroenterol 18, 783-789.
Van der Waaij D, Cohen BJ \& Anver MR (1974) Mitigation of experimental inflammatory bowel disease in guinea pigs by selective elimination of the aerobic gram-negative intestinal microflora. Gastroenterology 67, 460-472.

Van der Wiel-Korstanje J \& Winkler K (1975) The faecal flora in ulcerative colitis. J Med Microbiol 8, 491-501.

Venturi A, Gionchetti P, Rizzello F, Johansson R, Zucconi E, Brigidi P, Matteuzzi D \& Campiere M (1999) Impact on the composition of the faecal flora by a new probiotic preparation: preliminary data on maintenance treatment of patients with ulcerative colitis. Aliment Pharmacol Ther 13, 1103-1108.

Von Wulffen H, Russmann H, Karch H, Meyer T, Bitzan M, Kohrt TC \& Aleksic S (1989) Verocytotoxin-producing Escherichia coli O2:H5 isolated from patients with ulcerative colitis. Lancet 1, 1449-1450.

Walmsey RS, Anthony A, Sim R, Pounder RE \& Wakefield AJ (1998) Absence of Escherichia coli, Listeria monocytogenes, and Klebsiella pneumoniae antigens within inflammatory bowel disease tissues. $J$ Clin Patholol 51, 657-661.

Wehkamp J, Harder J, Weichenthal M, Mueller O, Herrlinger KR, Fellermann K, Schroeder JM \& Stange EF (2003) Inducible and constitutive beta-defensins are differentially expressed in Crohn's disease and ulcerative colitis. Inflamm Bowel Dis 9, 215-223.

Woywodt A, Ludwig D, Neustock P, Kruse A, Schwarting K, Jantschek G, Kirchner H \& Stange EF (1999) Mucosal cytokine expression, cellular markers and adhesion molecules in inflammatory bowel disease. Eur J Gastroenterol Hepatol 11, 267-276.

Yamaguchi Y, Nagase T, Makita R, Fukuhara S, Tomita T, Tominaga T, Kurihara H \& Ouchi Y (2002) Identification of multiple novel epididymis-specific beta-defensin isoforms in humans and mice. J Immunol 169, 2516-2523.

Zhao C, Wang I \& Lehrer RI (1996) Widespread expression of beta defensin hBD-1 in human secretory glands and epithelial cells. FEBS Lett 396, 319-325.

Zoetendal EG, von Wright A, Vilpponen-Salmela T, Ben-Amor K, Akkermans AD \& de Vos WM (2002) Mucosa-associated bacteria in the human gastrointestinal tract are uniformly distrubuted along the colon and differ from the community recovered from feces. Appl Environ Microbiol 68, 3401-3407. 